International Journal of Physical Research, $7(2)(2019) 37-47$
SPC
Website: www.sciencepubco.com/index.php/IJPR
Research paper

\title{
Design of a hybrid solar photovoltaic system for Gollis University's administrative block, Somaliland
}

\author{
Jama S. Adam 1, 4, $5 *$, Adebayo A. Fashina ${ }^{1,2,3}$ \\ ${ }^{1}$ Department of Electrical and Telecommunication Engineering, Kampala International University. \\ P.O. Box 20000, Kampala Uganda \\ ${ }^{2}$ Department of Physical Sciences, Kampala International University. P.O. Box 20000, Kampala Uganda \\ ${ }^{3}$ School of Graduate Studies and Research, Gollis University, 26 June District Hargeisa, Somalia \\ ${ }^{4}$ Department of Electrical and Telecommunication Engineering Gollis University, 26 June District Hargeisa, Somalia \\ ${ }^{5}$ Department of Renewable Energy, REHUBCO Renewable Energy CO., 26 June District Hargeisa Somalia \\ *Corresponding author E-mail: adebayofashina@gmail.com
}

\begin{abstract}
This work presents the design of a 100kVA hybrid solar power system for Gollis University's administrative block, Hargeisa, Somaliland. Prior to the system design, a preliminary field work on the site was performed to essentially measure the power/energy consumption of Gollis university's administrative block. The results from the site survey was then used to select the appropriate equipment and instrument required for the design. This was achieved by calculating the energy consumption and then sizing the solar panel, battery, inverter and charge controller. The battery back-up time analysis at full load was also carried out to determine the effectiveness of the inverter size chosen. The inverter system was modeled and simulated using the MATLAB/Simulink software package. The simulation was used to study the reliability of the size of inverter chosen for the design, since the failure of most photovoltaic systems is ascribed to inverter failures. The results from the MATLAB/Simulink simulation showed that the inverter selected for the hybrid PV system has the ability to maximize the power produced from the PV array, and to generate sinusoidal AC voltage with minimum output distortion. The results also revealed that the PV solar system can provide a back-up time of 47.47 hours. The implications of the results are then discussed before presenting the recommendations for future works.
\end{abstract}

Keywords: Photovoltaic Systems; Somaliland; Hybrid Solar Power System; MATLAB.

\section{Introduction}

In recent years, the increasing demand of energy in the world has led many nations to adapt the use of renewable energy technologies in their energy mix [1-6]. These renewable energy technologies include: Tidal, Geothermal, Biomass, Wind, Hydropower and Solar as in the case of this research work. Solar energy is one of the most promising renewable energy sources [1], [2], with absolutely unlimited potential [3]. It is non-polluting [7], inexhaustible [8] and ultimate source of energy that is eco-friendly [1], [6-8].

Furthermore, solar energy is obtained using some solar energy technologies that are broadly categorize into two groups, namely: solarthermal and solar photovoltaic (PV). Solar thermal applications convert electromagnetic waves from the sun into heat energy [9], while solar photovoltaic applications convert the solar radiation from the sun into electricity [10]. The radiation from the sun is transmitted as Electromagnetic $(\mathrm{EM})$ wave at a rate of about $3.8 \times 10^{24} \mathrm{~kW} / \mathrm{sec}$ and with an average solar radiation level of about $5.08 \times 10^{12} \mathrm{kWh} / \mathrm{day}$ [1], [8].

According to the International Energy Agency (IEA) data (See Figure 1), the global energy consumption is estimated to be 18,608 terawatthours [2], [11] with only $3 \%$ of the world energy consumed in Africa [12], as shown in Figure 2. In spite of the meaningful progress that has been recorded in the energy industry to make available adequate and reliable energy, about 1.2 billion people in the world [5], [13] and $80.9 \%$ of Somalia's population still have no access to electricity [12]. As a result, the cost of electricity in Somalia is one of the highest in the world today [12], [13]. Damping the prospect of attracting capital inflows from investors as stability makes a return into the country [12-15].

Somalia is one of the East African countries that has substantial renewable energy resources that are fairly distributed across the country [14]. These include, a huge geothermal energy resources, an untapped hydropower, an enormous sunlight and many promising wind sites [14], [15]. However, financial, political and institutional instability are the major factors that have hindered the development of these readily available renewable energy resources [15]. Presently, $82 \%$ of the nation's total energy consumption is derived from the conventional biomass fuels such as firewood and charcoal, which is mainly used in the rural and poor communities $[15,16]$. In response to this exigent need however, efforts are been made to increase the use of renewable energy technologies as a means of providing a reliable and affordable 
solutions to the energy needs of Somalians [14], [15]. In addition, significant progresses are being made in terms of developmental initiatives of the wide-spread use of solar energy technologies in the capital, Mogadishu and other cities in Puntland and Somaliland [17].

The average solar energy potential of Somalia ranges from 5 to $7 \mathrm{kWhm}^{-2} /$ day with approximately 310 days of sunlight annually [15]. This amounts to about 2500 to 3000 hours of sunlight per year [15]. Some of the applications of solar energy that are utilized in Somalia are off-grid generation for health center and rural communities as well as water heater for buildings [15], [18]. In addition, researches have shown that, in some part of the country solar powered cooker are also in use. About 4,000 solar powered light were donated to Mogadishu by the Nordic International Support Foundation, the Turkish Government and the other Donor Agencies. Benadir Electric Company (BECO) is presently on the verge of designing and implementation a $5 \mathrm{MW}$ solar electricity for Mogadishu and $10 \mathrm{MW}$ solar electricity for two other cities [18]. With the introduction of the $15 \mathrm{MW}$ solar power, Somalia could avoid a 75,000 $\mathrm{tCO}_{2}$ of greenhouse gases [18]. Introducing a plan that will involve the design of renewable energy technology can boost electricity access in homes at a cost of about US 0.5 per unit (kilowatt hour) or half the current average tariff of US 1 per unit [13,14]. If such plan is well implemented, Somalia can have its installed power capacity grow from the current 85 megawatts (MW) to over 285 megawatts and thus potentially leading to a massive economic growth and diversification in its energy mix [13]. There is therefore, a need to explore the various ways to utilize the readily available solar energy resources in Somalia.

This work presents the design and simulate a hybrid solar photovoltaic system for the administrative block at Gollis University, Somaliland. The site preliminary field work involved data collection and site survey. The site survey identified the number of offices, daily energy consumption, number of equipment used by the administrative staff, working hours etc. Successively, during the design phase, careful planning and reasonable system sizing predictions were made to meet system requirement. The simulation of the appropriate inverter size was carefully carried out using MATLAB Simulink simulation package. The results were studied, analyzed and interpreted before elucidating the implications of the study.

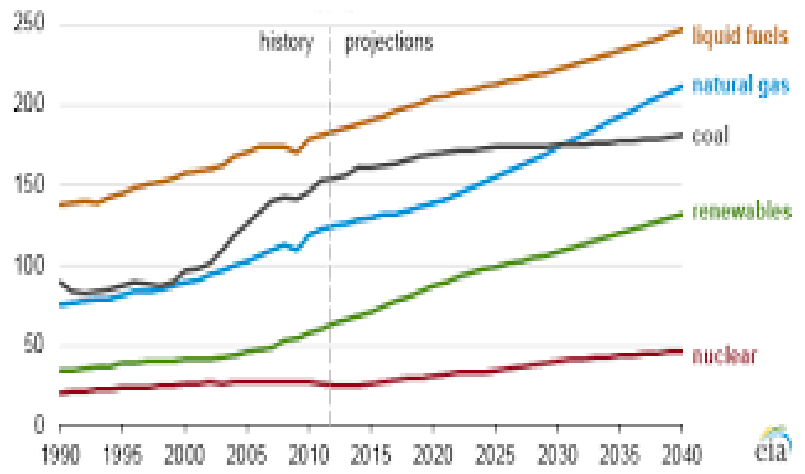

Fig. 1: World Energy Production by Region [11]

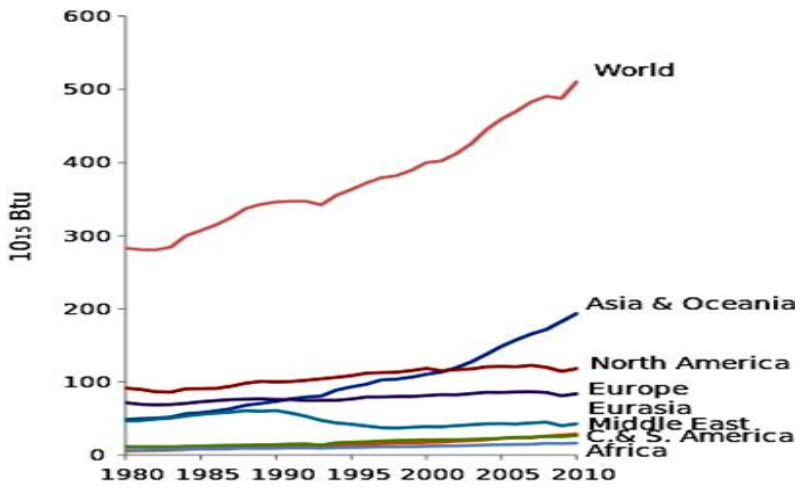

Fig. 2: The World's Increasing Demand of Energy [12].

\section{Photovoltaic cells and modules configuration}

The fundamental unit of a photovoltaic system is the PV cell and it generates a DC voltage between 0.5 to $12 \mathrm{~V}$ under the influence of sunlight [19], [20]. The normal silicon cell produces 2 to $3 \mathrm{~W}$ of power that is equivalent to 3 to $5 \mathrm{~A}$ and a cell voltage of about $0.6 \mathrm{~V}$ [20]. This is however, considered to be quite small for most applications and as such, the solar cells need to be arranged in series and/or and parallel in order to generate a worthwhile current and voltage that corresponds to the power demand [21]. Since, the nominal operating voltage of the system needs to be equal to the nominal voltage of the storage system, 28 or 36 pieces of solar cell are often connected in series to generate a module that can produce $12 \mathrm{Vdc}$ under the standard illumination condition in order to be able to work with $12 \mathrm{Vdc}$ batteries. On the other side, a module comprises of an encapsulated solar cell back contact and transport front side. A hardened and lowion glass serves as the substrate for encapsulation, illumination and as a supporting frame structure [22]. A thin Ethylene vinyl acetate (EVA) foil is placed between the glass and the solar cells [21], [22]. This is done to allow the cells to be well interconnected with thin contacts on the upper side of the semiconductor material (mostly silicon) [23]. Furthermore, PV panels usually come in various configuration and sizes to meet the energy needs of the end-users. Generally, PV panel are produced with a standard output voltage of 12 volts or 24 volts or 48 volts [21]. The design of the standard solar photovoltaic panels mostly consists of $36 \mathrm{c}-\mathrm{Si}$ cells which comes from the need to charge a $12 \mathrm{Vdc}$ voltage battery. If the solar cells produce up to $0.58 \mathrm{~V}$ cell voltage, then a typical $12 \mathrm{~V}$ PV panel will give 18.5 to 20.8 $\mathrm{V}$ peak output [21].

\subsection{Types of PV systems}


Based on the production of electrical energy, PV modules can be arranged into arrays in order to enhance electric output. Solar PV systems are thus, categorized based on their operational and functional requirement, and their component configurations.

\subsubsection{Grid-tied solar PV system}

Grid-tied, on-grid, grid-connected, grid intertie and grid back feeding are all terminology used to express the same idea i.e. a solar PV system that is connected to the utility power grid (See Figure 3) [24]. The power conditioning unit (PCU) is the primary component of grid-tied PV system. The PCU converts the DC power produced by the PV array into AC power in terms of the power and voltage quality requirement of the utility grid. A bi-directional interface is provided between the utility power network and the PV system's AC output circuits to allow the AC power generated by the PV system to either supply the electric load or to back-feed the grid when the output of the PV system is greater than the demand of the electrical load [24]. However, safety feature is highly required here to ensure that the PV system will not continually operate and feed-back into the utility grid in a case when the grid is down on maintenance or during a grid failure state [25].

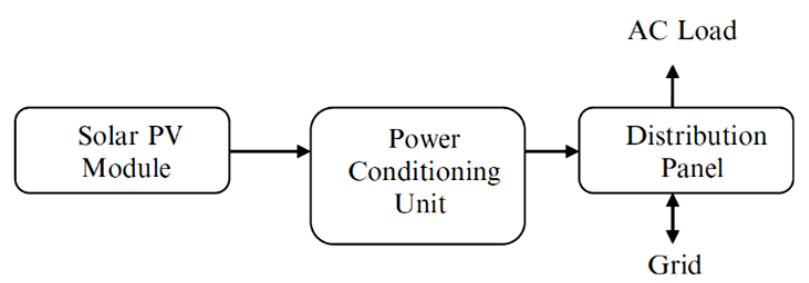

Fig. 3: Block Diagram of Grid-Tied Solar PV System [24].

\subsubsection{Off-grid solar PV system}

The off-grid or standalone PV systems are designed and sized to supply DC and/or AC electrical loads. It can also be a direct coupled system because the DC output of PV array is directly connected to a DC load (See Figure 4) [26]. It is important to note that indirect coupled systems are not connected to a battery bank since it only operates during sunlight hours. Furthermore, the maximum power point tracker (MPPT) is used between the load and the array to aid the better use of the available maximum power output from the PV array and also for matching the impedance of the electrical load to the maximum power output of the PV array (See Figure 5).

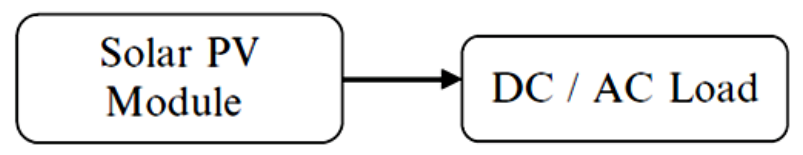

Fig. 4: Direct Coupled Solar PV System [26].

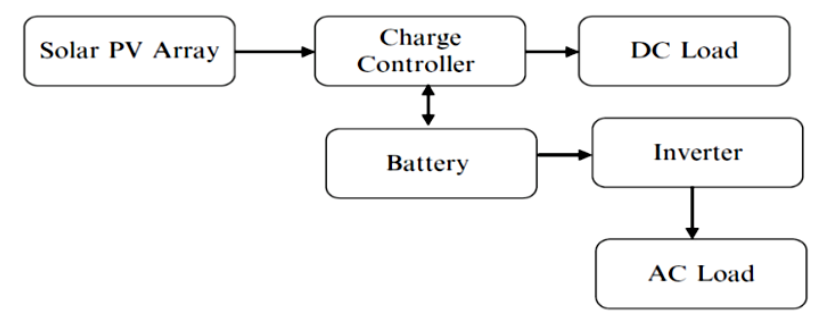

Fig. 5: Block Diagram of Off-Grid PV System with Battery Storage [24].

\subsubsection{PV-hybrid system}

In general, a hybrid system represents the combination of any two input sources and in this case, solar PV can be integrated with diesel generators, wind turbines or any other non-renewable or renewable energy sources (See Figure 6) [26]. Usually, the hybrid PV systems use battery bank to store energy/power output from PV arrays in order to accommodate a pre-defined period of inadequate sunshine (poor weather condition) when an alternative source is required to generate the production of power output. Furthermore, the PV-hybrid systems combine a PV array/module with another power sources (generally a diesel generator) that is sized to meet the base load demand this secures the supply of electrical energy while reducing the cost of maintenance and operation.

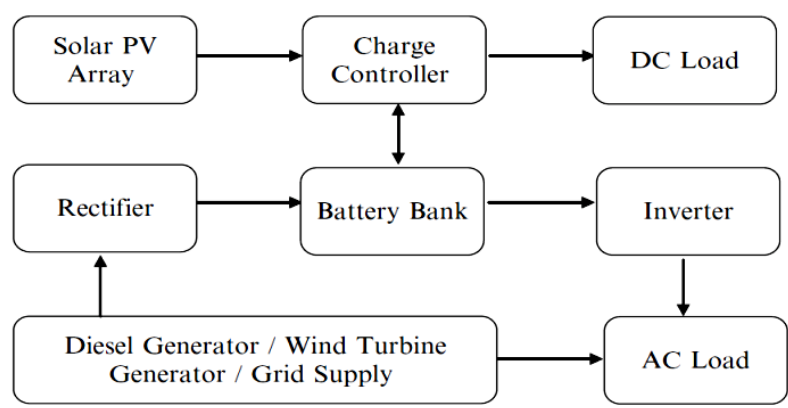

Fig. 6: Block Diagram of Photovoltaic Hybrid System [26]. 


\section{System design and simulation}

\subsection{Site survey}

The study site, Gollis University (See Figure 7), lies in the tropics with latitude $9.5624^{\circ} \mathrm{N}$, longitude $44.0770^{\circ} \mathrm{E}$ and an altitude of $4,377^{\prime}$ $\mathrm{m}$ in Hargeisa city, eastern region of Somalia. The site survey carried out on the site is basically to obtain the data required for the design of the PV system. The power rating of the different appliances and their numbers were recorded. The data obtained are then used to estimate the daily power consumption of Gollis University's Administration block.

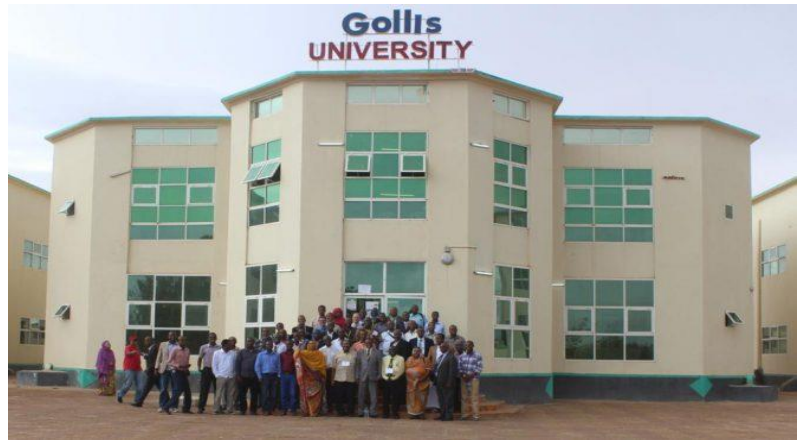

Fig. 7: Photography of Gollis University’s Administrative Block.

\subsection{System sizing}

Since the size of the PV system required depends on some factors such as, Gollis University's energy need, site location, climate etc., the steps used in the design of the PV solar system in this work are quite essential.

The first step in designing the solar PV system is to estimate the average daily power demand/consumption of each appliance to be used on the PV system. This was achieved by multiplying the power ratings of each appliance by the average number of hours of use. However, in order to allow energy lost in the system, the total appliances Watt-hours per day was multiplied by 1.3 to get the total Watt-hours per day, which must be provided by the PV panels.

The next step is to determine the size of the PV modules. To do this, the total peak watt $\left(\mathrm{W}_{\mathrm{p}}\right)$ is required. This depends on the size of the PV module and climate of site location. Thus, the "panel generation factor" is considered for the calculation of the total peak watt (This is different in each site location). For Somalia, the panel generation factor ranges from 3.21 to 4.63. After calculating the $W_{p}$, the number of PV panels for the system was then calculated. However, the resulting calculation is the minimum number of PV panels that must be used. But for a better performance, more PV modules can be added to the installation. If fewer PV modules are used, the system may not work during the cloudy periods and battery life will be shortened.

An inverter is used in the PV system since AC power output is needed. Ideally, the input rating of the inverter should never be lower than the total watt of appliances and the inverter must have the same nominal voltage as that of the battery. Hybrid systems as in the case of this work, the inverter is considered to be enough to handle the total amount of Watts that is required by the load. Thus, the inverter size should be $25-30 \%$ bigger than the total Watts of appliances as a standard. It is important to note that in case of appliance type such as motor or compressor (like in the water dispenser here) then inverter size should be minimum 3 times the capacity of those appliances and must be added to the inverter capacity to handle surge current during starting.

The battery type selected for the solar PV system in this work is deep cycle battery. Deep cycle battery is specifically designed to be discharged to low energy level and rapid recharged or cycle charged and discharged day after day for years [27], [28]. The battery capacity is considered to be large enough to store sufficient energy to operate the appliances at night and cloudy days.

According to standard practice, the sizing of solar charge controller is achieved by multiplying the short circuit current ( $\left.\mathrm{I}_{\mathrm{sc}}\right)$ of the PV array by 1.3. This ensures that solar charge controller has enough capacity to handle the current from PV array and as such, an appropriate solar charge controller to match the voltage of PV array, and batteries is achieved.

\subsubsection{Radiation data}

The amount of helpful sunshine available for the PV panels on a regular day during the rainy/cloudy season (worst solar month) of the year is known as "Insolation value". On the other hand, Irradiance is the amount of electromagnetic energy that incident on the surface of the PV panel per unit time per unit area. Irradiance is also the average insolation divided by the average daily useful sunshine hours. In Somalia, (Hargeisa city) the monthly average solar insolation in July $\left(5.8 \mathrm{kWh} / \mathrm{m}^{2}\right)$ is the lowest solar energy month of the year (See Table 1). The solar energy incident on Hargeisa city is quite high in January with a monthly average daily radiation of $7.47 \mathrm{kWh} / \mathrm{m}^{2} / \mathrm{day}$, as shown in Table 2. The annual average of bright sunshine hours in Hargeisa city is 8.25 hours and the annual average solar insolation is $6.3 \mathrm{kWh} / \mathrm{m}^{2}$. These values are considered in the design of the solar PV system for Gollis University's Administrative block. The annual average sunshine duration is 3000 hours/year for Somalia [29]. The average temperature is about $29^{\circ} \mathrm{C}$ [29].

Table 1: The Monthly Average Value of Daily Sunshine Hours in Hargeisa City

\begin{tabular}{llll}
\hline Month & Minimum & Maximum & Average \\
\hline January & 9.5 & 11.9 & 10 \\
February & 9.7 & 12.7 & 11.1 \\
March & 9.5 & 12.1 & 9.8 \\
April & 9.8 & 12.2 & 9.9 \\
May & 7.7 & 11.7 & 9.2 \\
June & 5.8 & 9.3 & 7.9 \\
July & 4.6 & 8.7 & 7.8 \\
August & 6.1 & 9.1 & 8.0 \\
September & 6.8 & 10.5 & \\
\hline
\end{tabular}




\begin{tabular}{llll}
\hline October & 8.5 & 11.2 & 9.6 \\
November & 9.0 & 11.9 & 10.6 \\
December & 9.4 & 12.2 & 11.3 \\
Annual Average & 8.03 & 11.884 & 8.525 \\
\hline
\end{tabular}

Table 2: The Monthly Average Values of Daily Global Radiation in Hargeisa City

\begin{tabular}{ll}
\hline Month & Solar Insolation $\left(\mathrm{kWh} / \mathrm{m}^{2} /\right.$ day $)$ \\
\hline January & 7.47 \\
February & 6.91 \\
March & 7.0 \\
April & 6.85 \\
May & 6.23 \\
June & 5.55 \\
July & 5.18 \\
August & 5.94 \\
September & 5.60 \\
October & 6.34 \\
November & 6.24 \\
December & 6.38 \\
Average & 6.3 \\
\hline
\end{tabular}

\subsubsection{Energy/power capacity calculations}

Table 3 provides the estimates of the daily energy/power consumption of Gollis University's Administrative block (GUAB). In determining the total energy/power consumption at GUAB, the power consumption for each appliance were calculated and presented in Table 3 . The estimation of the average number of hours required for each appliance to utilize power in a day is also presented in Table 3.

Table 3: Summary of the Estimation of Total Power and Energy Consumption of GUAB

\begin{tabular}{|c|c|c|c|c|c|}
\hline Appliances & $\begin{array}{l}\text { Unit Power Rating } \\
\text { (W) }\end{array}$ & $\begin{array}{l}\text { Possible number of } \\
\text { units }\end{array}$ & $\begin{array}{l}\text { Overall Power Rating } \\
\text { (W) }\end{array}$ & $\begin{array}{l}\text { Daily hours } \\
\text { (h/day) }\end{array}$ & $\begin{array}{l}\text { Daily Energy consumption } \\
\text { (Wh/day) }\end{array}$ \\
\hline Computers & 150 & 30 & 4500 & 8 & 36,000 \\
\hline LED Projectors & 150 & 3 & 450 & 5 & 2,250 \\
\hline Bulbs & 25 & 150 & 3750 & 7 & 26,250 \\
\hline Water dispenser & 95 & 8 & 760 & 7 & 5,320 \\
\hline Television & 100 & 4 & 400 & 7 & 2,800 \\
\hline Fan & 80 & 10 & 800 & 5 & 4,000 \\
\hline $\begin{array}{l}\text { Phone charge } \\
\text { Industrial }\end{array}$ & 8 & 30 & 240 & 2 & 480 \\
\hline $\begin{array}{l}\text { Printer/photo cop- } \\
\text { ier }\end{array}$ & 186 & 2 & 372 & 3 & 1,116 \\
\hline Laptop & 65 & 10 & 650 & 3 & 1,950 \\
\hline Total & 859 & & 11,922 & 47 & 80,166 \\
\hline
\end{tabular}

The calculation of the power consumption demands (from the PV panels) is as follows:

\begin{tabular}{ll}
\hline Total appliance use & $=80,166 \mathrm{WH} /$ day \\
Energy lost in the system & $=1.3$ \\
Total PV panels energy needed & $=$ Total appliance use $\times$ Energy lost in the system $(1)$ \\
Total PV panels energy needed & $=80,166 \times 1.3=104,215.8 \mathrm{WH} /$ day. \\
\hline
\end{tabular}

\subsubsection{PV panel sizing}

Based on the estimation of the total energy needed from the PV panels/day (104,215.5 Wh/day), a $24 \mathrm{Vdc}, 305 \mathrm{~W}_{\mathrm{p}}$ photovoltaic module is selected to power the PV system. Furthermore, to get the panel generation factor (Wh/day/Wp capacity), the daily sun hours is multiplied by 0.62 . In this work, the lowest and highest solar months are calculated and obtained as follows:

For the lowest, $5.18 \times 0.62=3.21$

For highest, $7.47 \times 0.62=4.63$

So, the panel generation factor for Somalia is between 3.21- 4.63. Ideally, the lowest value is chosen to accommodate the cloudy/rainy seasons. In this case, 3.21 is chosen as panel generation factor of Somalia. Thus, we have that [30]:

Total $\mathrm{W}_{\mathrm{p}}$ of PV panel capacity needed $=\frac{\text { Total PV panels energy needed }}{\text { Panel generation factor for Somalia }}$

Total $\mathrm{W}_{\mathrm{p}}$ of PV panel capacity needed $=\frac{104,215.8}{3.21}=32465.98$

Number of PV panels needed $=\frac{32465.98}{305}=106.5$

Actual requirement $=110$ or more modules

So, the PV system design will be powered by at least 110 modules of $305 \mathrm{~W}_{\mathrm{p}}$ PV module. 


\subsubsection{Inverter sizing}

Total Watt of all appliances $=11,922 \mathrm{~W}$

For safety, the inverter should be considered $25-30 \%$ bigger in size. Thus, we have that:

$\frac{28}{100} \times 11,922=3,338.16$

The inverter size $=11,922+3,338.16=15,260.16 \mathrm{~W}$

The inverter size should be about $15,260 \mathrm{~W}(15.3 \mathrm{kVA})$ or greater.

\subsubsection{Battery sizing}

To size the batteries, the following parameters were used in the calculation:

Total appliances use $=80,166 \mathrm{Wh} /$ day

Nominal battery voltage $=24 \mathrm{~V}$

Days of autonomy $=3$ days

Battery loss $=0.85$

Battery depth of discharge $(\mathrm{DOD})=0.5$

$$
\text { Battery Capacity }(\mathrm{Ah})=\frac{\text { Total Watt-hours per day used by appliances }}{\text { (battery loss } \mathrm{x} \text { DOD x nominal battery voltage })} \times \text { Days of Autonomy [30] }
$$

Battery Capacity $(\mathrm{Ah})=\frac{80166 \mathrm{Wh} / \mathrm{day}}{(0.85 \times 0.5 \times 24)} \times 3=23578.24$

Total Ampere-hours required is 23578.24 Ah. So, the will should be rated 24 V 23,578 Ah for 3-day autonomy.

\subsubsection{Charge controller sizing}

Following the National Renewable Energy Laboratory (NREL) USA's recommendation, the solar charge controller was calculated based on the $\mathrm{I}_{\mathrm{sc}}$ in Table 4.

Solar charge controller rating $=110$ strings $\times 5.55 \times 1.3=793.65 \mathrm{~A}$.

So, the solar charge controller will be rated $\sim 793 \mathrm{~A}$ at $24 \mathrm{~V}$ or greater.

Table 4: PV Module Specifications

\begin{tabular}{ll}
\hline Specifications & Ratings \\
\hline $\mathrm{P}_{\max }$ & $305.2 \mathbf{W}_{\mathbf{p}}$ \\
$\mathrm{V}_{\max }$ & $35.4 \mathrm{Vdc}$ \\
$\mathrm{I}_{\max }$ & $44.9 \mathrm{~A}$ \\
$\mathrm{Voc}$ & $64.2 \mathrm{~V}$ \\
Isc & $5.55 \mathrm{~A}$ \\
Irradiance & $1000 \mathrm{Wm}^{2}$ \\
\hline
\end{tabular}

\subsection{MATLAB/Simulink model of inverter}

The MATLAB/Simulink software package has several built-in mathematical models for components that make up a solar PV system. These include models for weather data processor, converter, PV panels, Inverter etc. The MATLAB/Simulink also has a user-friendly interface which enables the users to connect together different components of a PV system to develop a desired PV system capacity as shown in Figure 8.

\subsubsection{MATLAB/Simulink implementation}

In an effort to carry out the MATLAB/Simulink implementation, the model that is used in this study involved the preparation of input data and calculations of the design that are required for the simulation process. These inputs are specifications of the PV system design, as calculated in Section 3.2. A $100 \mathrm{kVA}$ PV array that was connected to a $25-\mathrm{kV}$ changeover panel (which connects the generator and utility grid) via a DC-AC boost converter and a three-phase three level voltage source converter (VSC). A maximum power point tracking (MPPT) was implemented in the boost converter by means of a Simulink model using the "incremental conductance + integral regulator" technique. In a more detailed way, the model contained PV array delivering a maximum of $100 \mathrm{kVA}$ at $1000 \mathrm{~W} / \mathrm{m}^{2}$ sun irradiance. 5-KHz DC-DC boost converter that is used to increase the voltage from PV natural voltage $273 \mathrm{Vdc}$ at maximum power to $500 \mathrm{Vdc}$. Switching duty cycle is then optimized by a MPPT controller that uses the "Incremental conductance +integral regulator" technique. This MPPT system automatically then varies the duty cycle in order to generate the required voltage to extract maximum power. The VSC converts the $500 \mathrm{Vdc}$ to $260 \mathrm{Vac}$ while it keeps unity power factor. A 10-kvar capacitor bank which is used to filter the harmonics produced by VSC. 100-kVA $260 \mathrm{~V} / 25 \mathrm{kv}$ three-phase coupling transformer. A combination of generator and utility grid (auto change over) panel. A 100-kVA PV array consisting of 110 strings of 3 series-connected modules connected in parallel $(110 \times 3 \times 305.2=100.7 \mathrm{kVA})$. 
Furthermore, as recommended by the NREL, specifications for the module used in this model was assigned as follows [31]:

Open circuit voltage: $\mathrm{V}_{\mathrm{oc}}=64.2 \mathrm{~V}$.

Short-circuit current: $\mathrm{I}_{\mathrm{sc}}=5.55 \mathrm{~A}$

Voltage and current at maximum power: $\mathrm{V}_{\mathrm{mp}}=35.4 \mathrm{~V}, \mathrm{I}_{\mathrm{mp}}=4.95 \mathrm{~A}$.

The module parameter of the PV array block assisted in choosing the best choice among the various array types. Also, the PV array block has two inputs that allow the variation sun irradiance and temperature input possible. The irradiance and temperature profiles are defined by a signal builder block which is connected to the PV array inputs as shown in Figure 8.

\subsubsection{Inverter model}

For the development of the inverter model, the power system block set provided the required components such as the batteries, inductors, capacitors, resistors, full bridge etc. The pulse generation circuit is adapted in this model as shown in Figure 9. The converters used in this model are built with the IGBT/Diode block that is basically the building block of all VSCs. The IGBT/Diode block used in the Simulink implementation is a simplified model of an IGBT (or GTO or MOSFET)/Diode pair as illustrated in Figure 9. For more detailed representation, the individual IGBT and diode blocks were varied and the VSCs were also controlled in open loop with the PWM generator block. The two circuits use the same DC voltage $(\mathrm{Vdc}=400 \mathrm{~V})$, carrier frequency $(1080 \mathrm{~Hz})$ and modulation index $(\mathrm{m}=0.8)$.

In order to allow further signal processing, signals displayed on the two Scope blocks based differently. The input voltage was set based on the design specifications in the DC voltage source block. The internal resistance of the used switch and the diode was set to 0.001 ohm with the initial state "open".

\subsection{Battery backup time calculation}

One of the factors that determine the effectiveness of an inverter is the battery back-up time. It is therefore, important to carry out the analysis of the proposed PV system design from the energy capacity calculation for the design in section 3.2.2. The estimated load is projected to be $11,922 \mathrm{~W}$. Thus, the back-up time at full load for the designed system can be obtained as follows:

Battery power $=24 \times 23,578 \mathrm{Ah}=565,872 \mathrm{Wh}$

Estimated load $=11,922 \mathrm{~W}$

Back - up time $=\frac{\text { battery power capacity }}{\text { Estimated load }}$

Back - up time $=\frac{565,872}{11,922}=47.47$ hrs.

Using the same procedure, the back-up times were also calculated for four (4) different loads with a load step of 2,000 W.

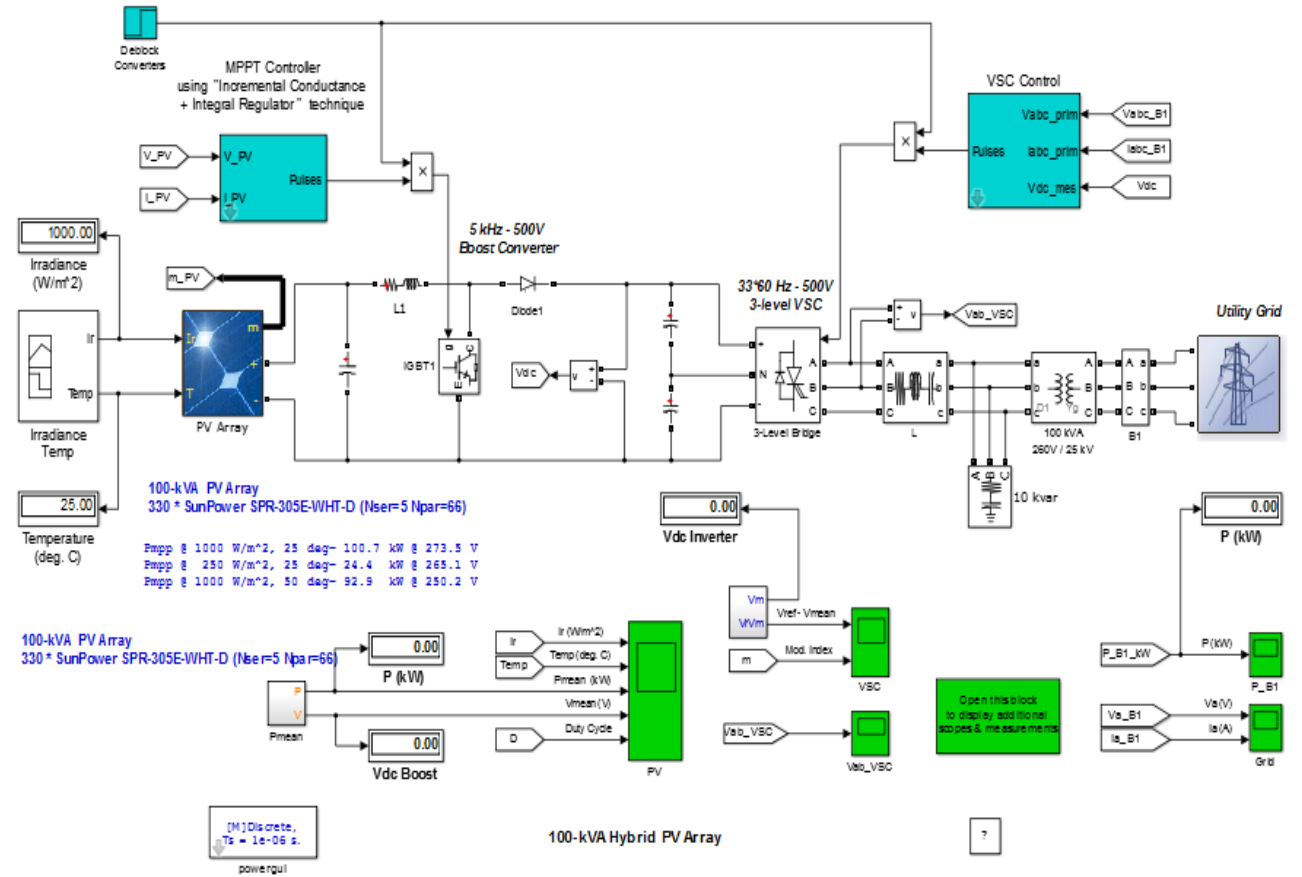

Fig. 8: Proposed PV Model Used in the MATLAB/Simulink Model. 

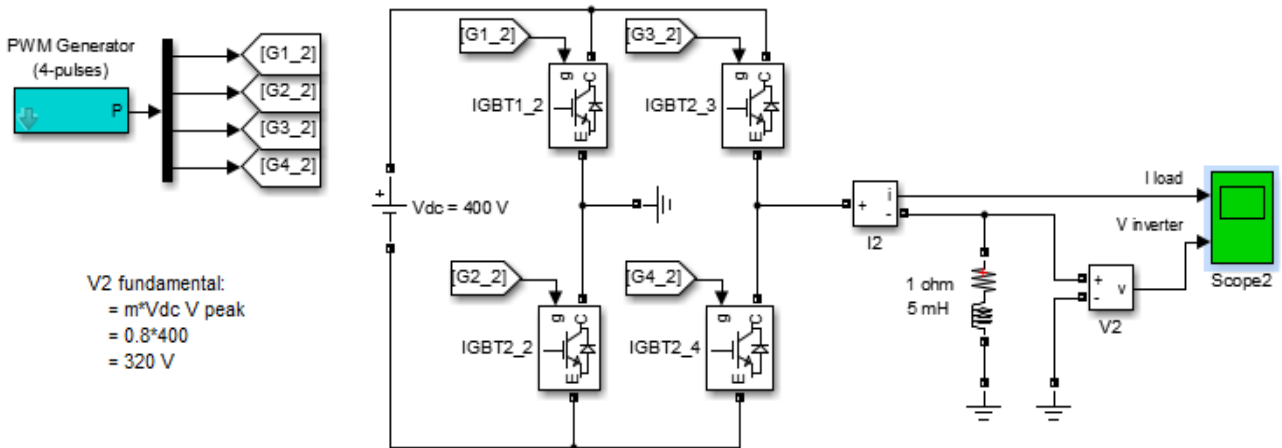

$=\mathrm{m}^{*} \mathrm{~V} d \mathrm{dc} V$ peak

$=0.8^{*} 400$

$=320 \mathrm{~V}$

DC/AC Full-Bridge Inverter

Fig. 9: Block Diagram of the Single-Phase PWM Inverter Model.

\section{Results and discussion}

\subsection{System profile}

In this work, a hybrid PV design of $100 \mathrm{kVA}$ was successfully carried out. The PV system has the following main units: PV module unit, inverter unit, charge controller unit, battery unit and control unit. As shown in Table 5, 110 strings of 3 series-connected $305.2 \mathrm{~W}_{\mathrm{p}}$ modules connected in parallel were used to achieve a required energy of $107 \mathrm{kVA}$ from the PV panels. It can also be deduced from Table 5 that the inverter size required for the system design in this work is $15,260 \mathrm{~W}(\sim 16 \mathrm{kVA})$ and the charge controller size is $793 \mathrm{~A}$ at $24 \mathrm{~V}$. In addition, a battery bank of $24 \mathrm{~V}, 23,578 \mathrm{Ah}$ in size was used in the design. This design is incorporated with both utility grid and generator as specified for hybrid systems. This is due to the fact that presently in Somalia, sudden power failure from the national/utility grid is a predominant occurrence that is often experienced at Gollis University. As such, an automatic control features (charge-over panel) that can automatically change inverter to utility/generator during the low sunshine days and vice versa was used. This also regulates the battery charging from any of the three sources (PV panels or utility grid/generator) by connecting or disconnecting in case there is a fall or rise in the voltage source.

Table 5: Summary of the Hybrid Solar PV System Designed for Gollis University's Administrative Block

\begin{tabular}{lll}
\hline S/N & Design Parameters & Design Capacity \\
\hline 1 & Power consumption demands & $104,215.8 \mathrm{Wh} /$ day \\
2 & PV panel & 110 modules \\
3 & Inverter & $15,260 \mathrm{~W}$ \\
4 & Battery bank & $24 \mathrm{~V} 23578 \mathrm{Ah}$ \\
5 & Charge controller & $793.65 \mathrm{~A}$ \\
\hline
\end{tabular}

\subsection{Battery backup time analysis}

Table 6 shows the results for the back-up time at the different loads. From the battery back-up time analysis at full load, the system can provide a back-up time of 47.47 hours. However, it is expected that since the equipment will often not work at the same period, the load will sometimes vary within the PV design range from low-load to full-load. This is depicted in Figure 10. It can also be deduced from Figure 10 that as the load increases, the battery back-up time decreases. This implies that, during the weekend period, there will be a high back-up time since most equipment will not be in operation or in use.

Table 6: Back-Up Time at Different Loads

\begin{tabular}{ll}
\hline Load $(\mathrm{W})$ & Back-up Time $(\mathrm{Hr})$ \\
\hline 3,922 & 144.3 \\
5,922 & 95.6 \\
7,922 & 71.44 \\
9,922 & 57.04 \\
11,922 & 47.47 \\
\hline
\end{tabular}

\subsection{MATLAB/Simulink simulation results}

The basic working principle of the solar inverter (power-electronic circuit) used in the research work is to convert the DC power from the PV panels into AC power at a desired output voltage and frequency. Within this context, both voltage source inverter and current source inverter were used in the simulation. According to the system design, a single-phase Pulse Width Modulation (PWM) full-bridge inverter is connected with the RLC load and four (4) IGBTs, as shown in Figure 9. However, obtaining a good result from such the topology needs careful analysis and the accurate choice of the low- and high-side combination of the IGBTs. The IGBTs are selected for this task because they have low switching losses and easy control ability.

Figure 11 shows the characteristics of the PWM generator according to the irradiation variation from $1000 \mathrm{~W} / \mathrm{m}^{2}$ to $200 \mathrm{~W} / \mathrm{m}^{2}$. The incremental task ratio changes according to the change in DC-AC inverter reference current. The frequency of the output current and voltage is 
controlled by variation of the specific periodic time, as shown in Figures 12 and 13. The PWM signal can then be utilized to control switches connected to a high-voltage bus, which will reproduce this signal at the suitable voltage. Introducing an LC filter implies that, the PWM signal in Figure 13 will be clean up into a close approximation of a sine wave, as shown in Figure 14. Though, this technique creates a clean source of AC power, few primary harmonics are generated by the full-bridge and they appear at twice the carrier frequency as depicted in Figure 14. As a result, the current obtained with the full-bridge though looks smooth still has little distortion.

Furthermore, since the solar inverter play the role of interfacing between the PV panels and AC power grid/generator, it is important discuss about its reliability. The simulation results from Figures $11-14$ have shown that the solar inverter has the ability to: (1) maximize the power that can be derived from the PV array, (2) match the DC voltage output produced by the PV array, (3) produce sinusoidal ac voltage with minimum output distortion, and (4) control the power flow. It is thus, certain that the inverter selected for hybrid PV system can successfully accommodate solar irradiation and load variations, and the control system can efficiently track the changes of hybrid power generation system and load demand.

Although, the site survey covered a wide range of investigation, further work is clearly needed to carry out shading analysis in order to be able to select the best position/place for the installation/implementation of the PV system. Future work can also be done to modify the design developed in this study, by further exploring the design of stand-alone (off-grid) or grid-tied system for Gollis University. Due to the fluctuation in the prices of the Solar PV components, the cost and economic analysis were not done in this work. Further research is thus needed to strengthen the survey results obtained, by carrying out the adequate cost and economic analysis of the PV system as compared to the conventional source of energy used by Gollis University.

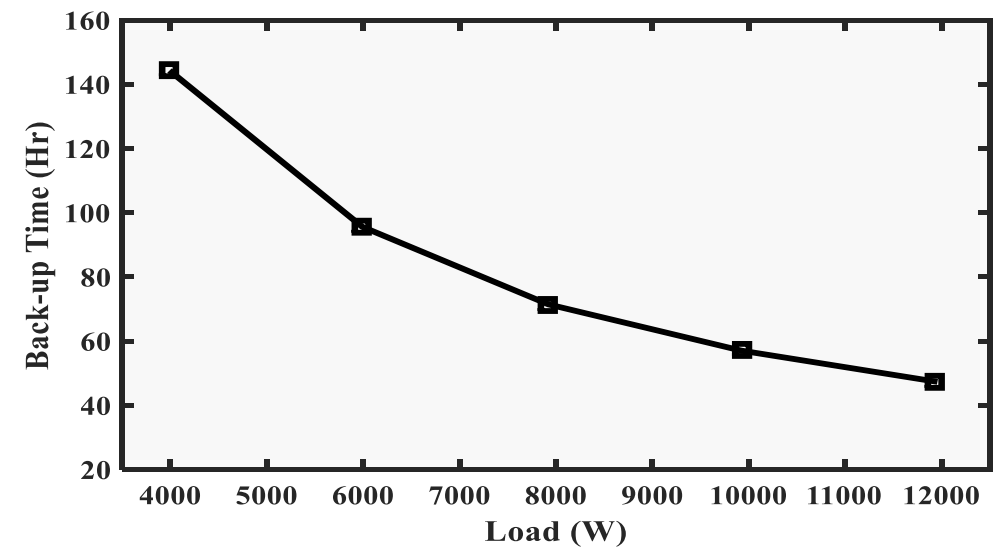

Fig. 10: Load Variation with Back-Up Time.

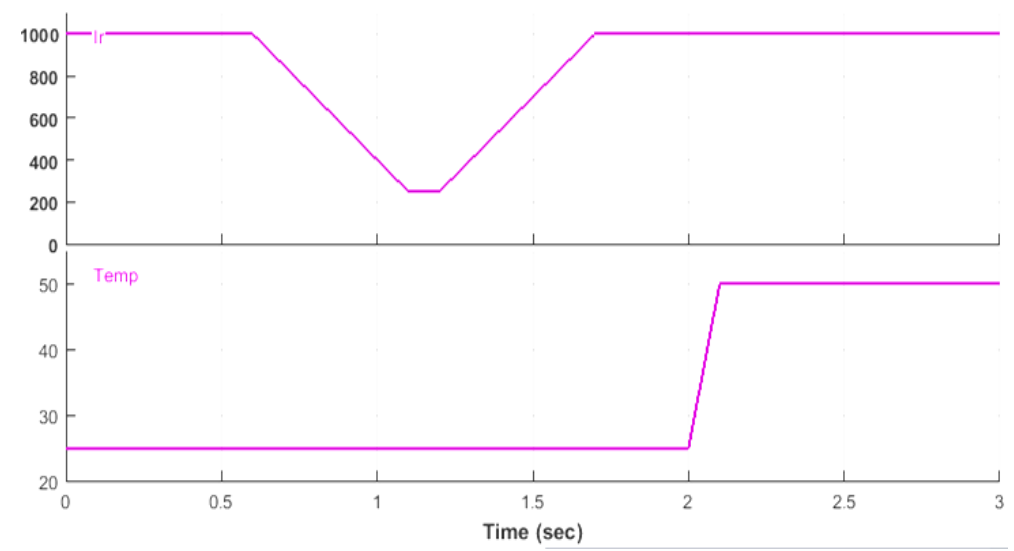

Fig. 11: Characteristic of the PWM Generator in Radiation $1000 \mathrm{~W} / \mathrm{M}$ and Temperature $25^{\circ} \mathrm{C}$.

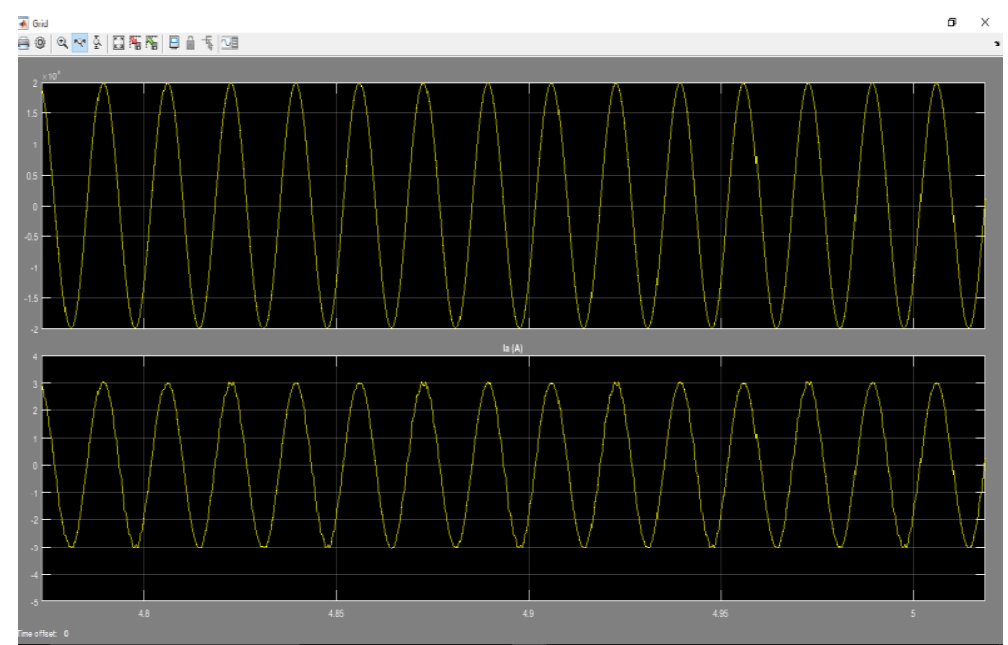

Fig. 12: High-Voltage Filtered Inverter Output Waveform Generating PWM Control. 


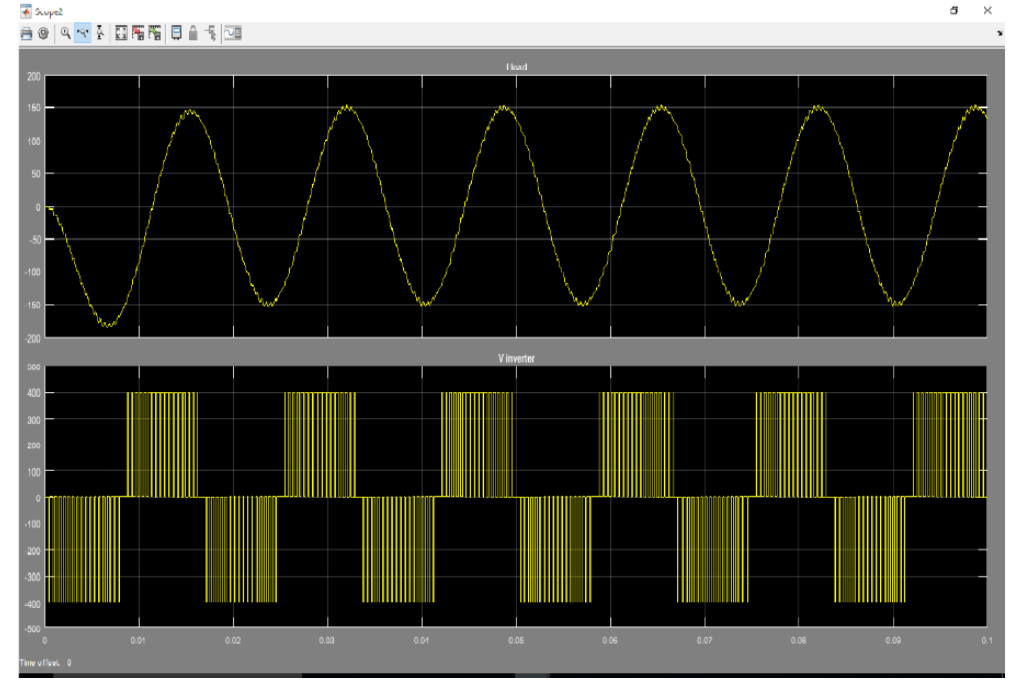

Fig. 13: Unfiltered High-Voltage PWM Output with 200W Load.

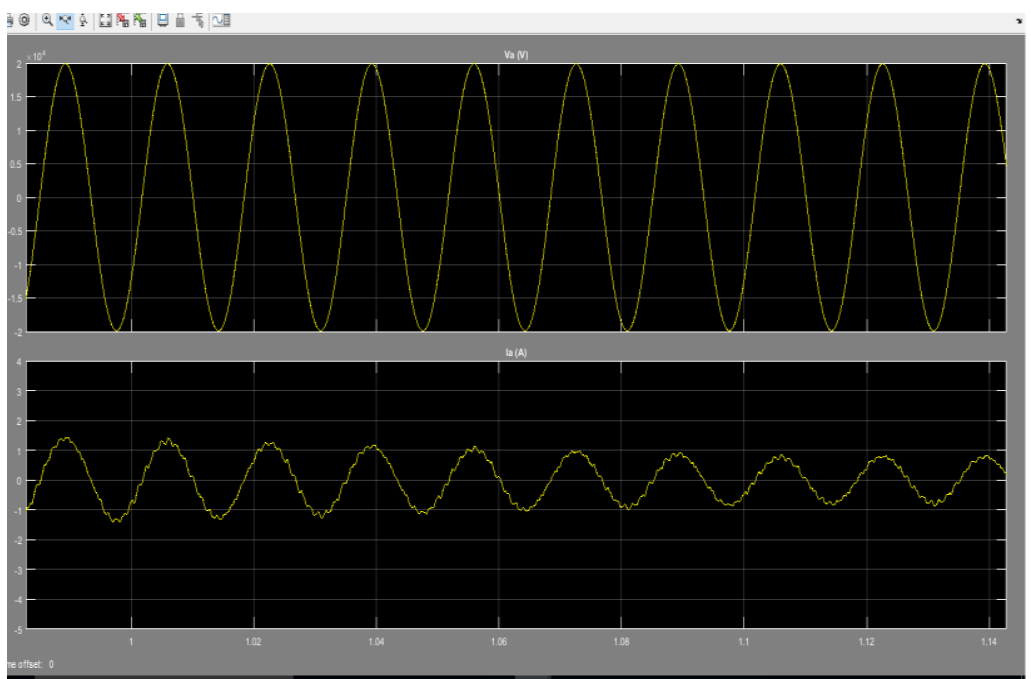

Fig. 14: Filtered High-Voltage PWM Output with Resistive Load Current.

\section{Conclusion}

A 100-kVA photovoltaic hybrid system was successfully designed. The design includes, PV panel sizing, charge controller sizing, inverter sizing and battery bank sizing. Prior to the design, a site survey was carried out at Gollis University's Administrative block to obtain the required data for the PV solar design. According to the results from the site survey, the daily energy/power consumption of Gollis University's Administrative block is estimated to be $80,166 \mathrm{Wh} /$ day and the required energy from the PV panel is obtained to be $104,215 \mathrm{Wh} / \mathrm{day}$. The data obtained were used to identify the suitable solar PV system for Gollis University's administrative block.

In an effort to study the reliability of the selected inverter size, the MATLAB/Simulink software package was used for modeling and simulation. The results from the MATLAB/Simulink simulation showed that the inverter selected for hybrid PV system has the ability to maximize the power produced from the PV array, and to generate sinusoidal AC voltage with minimum output distortion. This implies that the size of the inverter selected can successfully accommodate solar irradiation and load variations, and the control system can efficiently track the changes of hybrid power generation system and load demand.

Furthermore, the battery back-up time analysis at full load showed that the PV solar system can provide a back-up time of 47.47 hours. However, the analysis also showed that when the load demand decreases, the back-up time increases, and this is actually expected, since most of the equipment do not operate at the same time.

\section{Acknowledgement}

The authors are grateful to thank Dr. Atiku Abubakar Farooq for useful scientific discussion.

\section{References}

[1] Armaroli, N., and Vincenzo B., "Solar electricity and solar fuels: status and perspectives in the context of the energy transition." Chemistry-A European Journal 22, no. 1 (2016): 32-57. https://doi.org/10.1002/chem.201503580.

[2] IEA. World Energy Outlook; OECD/IEA: Paris, France, 2016.

[3] REN21. Renewables 2015 Global Status Report; REN21 Secretariat: Paris, France, 2015.

[4] Adebayo A. Fashina, Oluwole O. Akiyode and Dahiru M. Sanni "The status quo of rural and renewable energy development in Liberia: Policy and Implementation" SPC Journal of Energy 1(1), 9-20, 2018. 
[5] Adebayo Fashina, Mustafa Mundu, Oluwole Akiyode, Lookman. Abdullah, Dahiru Sanni and Living Ounyesiga, "The Drivers and Barriers of Renewable Energy Applications and Development in Uganda: A Review" Clean Technologies 1(1), 1-31, 2018. https://doi.org/10.3390/cleantechnol1010003.

[6] A. A. Fashina, S. T. Azeko, J. Asare, C. J. Ani, V. C. Anye, E. R. Rwenyagila, B. Dandogbesi, O. Oladele, M. Dyeris, “A Study on the Reliability and Performance of Solar Powered Street Lighting Systems." International Journal of Scientific World 7(4), 110-118, 2017 https://doi.org/10.14419/ijsw.v5i2.8109.

[7] Wang, C., Fei W., Xinlin Z., Yu Y., Yongxian S., Yuyao Y., and Hongou Z. "Examining the driving factors of energy related carbon emissions using the extended STIRPAT model based on IPAT identity in Xinjiang." Renewable and Sustainable Energy Reviews 67 (2017): 51-61. https://doi.org/10.1016/j.rser.2016.09.006.

[8] Fraunhofer ISE. Photovoltaic Report; Fraunhofer ISE: Freiburg, Germany, 2015

[9] Soares, N., Costa J. J., Gaspar A. R., and Santos P., "Review of passive PCM latent heat thermal energy storage systems towards buildings' energy efficiency." Energy and buildings 59 (2013): 82-103. https://doi.org/10.1016/j.enbuild.2012.12.042.

[10] Romero-Cadaval E., Giovanni S., Leopoldo G. F., et al. "Grid-connected photovoltaic generation plants: Components and operation." IEEE Industrial Electronics Magazine 7, no. 3 (2013): 6-20. https://doi.org/10.1109/MIE.2013.2264540.

[11] IEA. Technology Roadmap: Solar Photovoltaic Energy 2014 edition; OECD/IEA: Paris, France, 2014.

[12] IRENA. Africa 2030: Roadmap for a Renewable Energy Future; IRENA: Masdar City United Arab Emirates, 2015.

[13] IRENA. Solar PV in Africa: Costs and Markets; IRENA: Masdar City, United Arab Emirates, 2016.

[14] Munslow, B., Phil O., Donna P., and Peter P., "Energy and development on the African East Coast: Somalia, Kenya, Tanzania and Mozambique." Ambio (1983): 332-337.

[15] Abdilahi, A. M., Abdul H. M. Y., Mohd W. M., Omar T. K., Alshammari F. S., and Faizah M. N., "Feasibility study of renewable energy-based microgrid system in Somaliland 's urban centers." Renewable and Sustainable Energy Reviews 40 (2014): 1048-1059. https://doi.org/10.1016/j.rser.2014.07.150.

[16] T. M. Tong, J. Asare, E. R. Rwenyagila, V. Anye, O. K. Oyewole, A. A. Fashina and W. O. Soboyejo, "A Study of Factors that Influence the Adoption of Solar Powered Lanterns in a Rural Village in Kenya" Perspectives on Global Development and Technology 14(4), 448-491, 2015 https://doi.org/10.1163/15691497-12341356.

[17] Pleßmann, G., Matthias E., Markus H., and Christian B., "Global energy storage demand for a $100 \%$ renewable electricity supply." Energy Procedia 46 (2014): 22-31. https://doi.org/10.1016/j.egypro.2014.01.154.

[18] Dualeh, O. H., and Abdillahi H. M., "Alternatives energies and reduction of dependence on charcoal in Somaliland." In Sixth resource-based conflicts (RBC) conference in Hargeisa, Somaliland. 2005.

[19] Fahrenbruch, A., and Richard B., "Fundamentals of solar cells: photovoltaic solar energy conversion". Elsevier, 2012.

[20] Rauschenbach, H. S., "Solar cell array design handbook: the principles and technology of photovoltaic energy conversion". Springer Science \& Business Media, 2012.

[21] Shepherd, C. M., "Design of primary and secondary cells II. An equation describing battery discharge.", Journal of the Electrochemical Society 112 , no. 7 (1965): 657-664. https://doi.org/10.1149/1.2423659.

[22] Razykov, T., Chris M., Don M. S., Elias F., Harin S. Ullal S., and Hari M. Upadhyaya.,"Solar photovoltaic electricity: Current status and future prospects." Solar Energy 85, no. 8 (2011): 1580-1608. https://doi.org/10.1016/j.solener.2010.12.002.

[23] Khan, A. I., "Pre-1900 "semiconductor research and semiconductor device applications." In Proc. IEEE Conf. History Electron. pp. 1-21. 2004.

[24] Tsukamoto, O., Okayasu T., and Yamagishi K., "Study on islanding of dispersed photovoltaic power systems connected to a utility power grid." Solar energy 70, no. 6 (2001): 505-511. https://doi.org/10.1016/S0038-092X(00)00145-6.

[25] Zhang, P., Yang W., Weidong X., and Wenyuan L., "Reliability evaluation of grid-connected photovoltaic power systems." IEEE transactions on sustainable energy 3, no. 3 (2012): 379-389. https://doi.org/10.1109/TSTE.2012.2186644.

[26] Rehman, S., and Ibrahim E., "Performance evaluation of an off-grid photovoltaic system in Saudi Arabia." Energy 46, no. 1 (2012): 451-458. https://doi.org/10.1016/j.energy.2012.08.004.

[27] Saris, W. E., and Irmtraud N. G., "Survey Items in Batteries." Design, Evaluation, and Analysis of Questionnaires for Survey Research (2nd ed.), Hoboken, NJ: John Wiley \& Sons, doi10 (2014): 9781118634646.

[28] Wakefield, I. N., "Apparatus and method for identifying and charging batteries of different types." U.S. Patent 6,625,477, issued September 23, 2003.

[29] Dualeh, O. H., and Abdillahi H. M., "Alternatives energies and reduction of dependence on charcoal in Somaliland." In Sixth resource-based conflicts (RBC) conference in Hargeisa, Somaliland. 2005.

[30] Kaabeche, A., Belhamel M., and Ibtiouen R., "Sizing optimization of grid-independent hybrid photovoltaic/wind power generation system." Energy 36, no. 2 (2011): 1214-1222. https://doi.org/10.1016/j.energy.2010.11.024.

[31] Marion, B., Adelstein J., Boyle K., Hayden H., Hammond B., Fletcher T., et al. "Performance parameters for grid-connected PV systems." In Photovoltaic Specialists Conference, 2005. Conference Record of the Thirty-first IEEE, pp. 1601-1606. IEEE, 2005. 